\title{
British Columbia Forest Service's Science Program: Science to support sustainability
}

\author{
by Henry J. Benskin ${ }^{1}$ and Alan Vyse ${ }^{2}$
}

The prime mandate of the BC Forest Service's Forest Science Program is to bring scientific innovation to bear on sustainable forest management. For over 80 years, its staff has been an integral part of many significant changes to forest policies and practices. Decentralized researchers are in direct contact with local forest managers and resource users throughout the province, ensuring a focus on operationally relevant research as well as providing an accessible source of best available scientific knowledge to support policies and practices. Five core research activities within the program, including growth and yield, silviculture, forest genetics, ecology and earth sciences, yield valuable short and long-term information about how to sustain ecosystems, enhance timber production and manage forests for a variety of resource uses. In cooperation with partners and clients in universities, institutes, government agencies, the forest industry and others in both research and extension, program scientists and staff continue to deliver practical services to front-line practitioners and policy makers in British Columbia's rapidly changing forest sector.

Key words: scientific innovation, sustainable management, credibility, operationally relevant, policies, forest practices, partnerships

L'objectif premier du mandat du Programme des Sciences forestières du Service forestier de la Colombie-Britannique consiste à orienter l'innovation scientifique sur l'aménagement forestier durable. Depuis plus de 80 ans, son personnel a été un élément intégral de plusieurs modifications importantes au niveau des pratiques et des politiques forestières. Les chercheurs étant décentralisés sont en contact direct avec les gestionnaires forestiers locaux et les utilisateurs de la ressource partout dans la province, assurant une priorité de la recherche significative pour les opérations tout en constituant une source accessible des meilleures connaissances scientifiques disponibles pour appuyer les politiques et les pratiques. On retrouve quatre domaines principaux de recherche au sein du programme, qui comprennent la croissance et le rendement, la sylviculture, la génétique forestière, l'écologie et les sciences de la terre, les produits disponibles selon le rendement et l'information à court et long terme sur comment rendre durables les écosystèmes, l'accroissement de la production ligneuse et l'aménagement des forêts pour des utilisations multiples des ressources. En coopération avec des partenaires et des clients provenant des universités, des instituts, des organismes gouvernementaux, de l'industrie forestière et d'autres groupes tant du domaine de la recherche que du transfert technologique, les chercheurs du programme et le personnel continuent de fournir des services pratiques aux praticiens sur le terrain et aux personnes qui élaborent les politiques du secteur forestier de la Colombie-Britannique qui vit une modification rapide.

Mots-clés: innovation scientifique, aménagement durable, crédibilité, utilité opérationnelle, politiques, pratiques forestières, partenariats

Innovation in forest management is the driving force and the hallmark of success for the BC Forest Service's Forest Science Program. Since the first scientific investigations began more than eighty years ago, the influence of research findings has extended to almost every corner of the province's complex forest policy and management environment. Under the Program's prime mandate to bring scientific innovation to bear on sustainable forest management, the nature of the research has changed dramatically over time in keeping with new demands for knowledge.

In the earliest years, the principal challenges were to understand basic growth and yield relationships for harvest regulation and to find effective ways to regenerate cutovers in a relatively few coastal ecosystems. One of the first major research projects was led by Stig Schenström. He established six permanent experimental plots at the Cowichan Lake Research Station in 1929 and 1930 to test the effects of four different intensities and types of thinning in Douglas-fir stands. These plots are still under active study, generating a wealth of information for management purposes that were unforeseen at the time the work was initiated.

Throughout the mid 1900s, researchers continued to lead improvements in forest management by selecting natural

${ }^{1}$ Director, Research Branch, Ministry of Forests, 712 Yates St., Victoria, B.C. V8W 1L4. E-mail: henry.benskin@gems5.gov.bc.ca

${ }^{2}$ Forest Science Officer, Kamloops Forest Region, Ministry of Forests, 515 Columbia St., Kamloops, B.C. V2C 2T7. E-mail: alan.vyse@gems1.gov.bc.ca

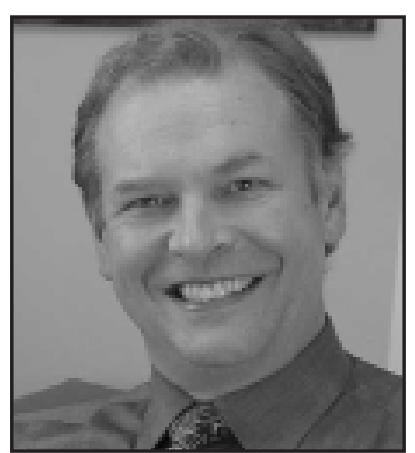

Henry J. Benskin

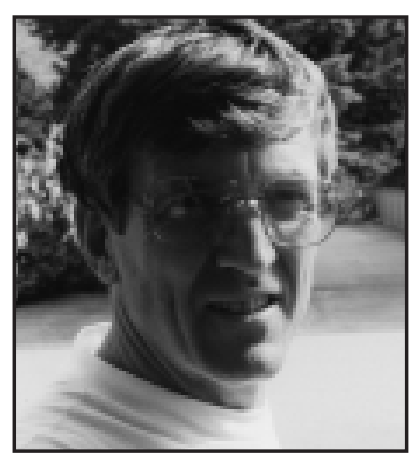

Alan Vyse seed sources, determining appropriate provenance rules to achieve successful deployment, establishing propagation and cultivation practices for nurseries and seed orchards, and improving field survival of new plantations. Dr. Alan Orr-Ewing's pioneering efforts to establish a practical tree breeding program for coastal Douglas-fir continue to yield valuable results.

By the 1960s, the complexity of forest management had begun an exponential increase, as had the demands on the Forest Science Program. The driving forces included expansion of the forest industry and population growth. Timber harvesting operations extended throughout the interior of the province, and into progressively more remote sites on the coast. Forest managers suddenly needed appropriate forest practices for previously unharvested species, in a far greater variety of ecological 
conditions, and on more difficult terrain. Industrial expansion brought demands for more timber, and for the ability to harvest and process materials to a higher level of utilization. The greater pervasiveness of timber harvesting also brought a greater awareness among a growing number of citizens about the impact of timber harvesting on other forest resources.

Researchers responded with an ambitious program that, in collaboration with other science providers and many diverse clients, has progressively built the scientific foundation to enhance timber supplies and other benefits from forest resources. At present, the Forest Science Program comprises 95 scientists and a somewhat smaller number of technical support and administrative staff. Staff members are located in six regional offices, two research stations and at the headquarters office in Victoria. The decentralized nature of the program places researchers in direct contact with local forest managers and resource users. This facilitates translation of best available science into policies and practices.

Within the Forest Science Program, there are five core research activities: forest genetics, growth and yield, silviculture, ecology, and earth sciences. Each of these activities has contributed significantly to the scientific basis for forest management in British Columbia, including key areas of policy such as the analysis of timber supplies and the development and revision of the Forest Practices Code.

The forest genetics activity carries out an aggressive slate of tree breeding projects and support studies. Tree improvement initiatives in collaboration with the Forest Genetics Council are enabled by funding from the Ministry of Forests and Forest Renewal BC, plus support of industrial and university co-operators. Active breeding programs are in place for 10 tree species, and second generation crossings and selections have begun. Goals have expanded from simply enhancing growth and form to include insect and disease resistance, resilience to climate change and improved wood properties. Forest geneticists also maintain the province's gene archives and clone banks that contain copies of all genetic resource collections. Provenance trials provide the material transfer guidelines for reforestation operations in the province and are also yielding an understanding of the response of various genetic stocks to global warming trends.

The growth and yield activity generates site productivity and forest growth estimates that are crucial for timber supply forecasts, silviculture investment decisions and silviculture prescription preparation. The Forest Science Program is responsible for maintaining provincial managed stand growth and yield databases, field installations and a number of widely used projection models. Recent work has included improving site productivity estimates, developing treatment response models for genetic improvement, and providing prediction capability for uneven-aged complex and partially cut stands.

The silviculture activity emphasizes research in stand management and silviculture systems. A strategic network of long-term installations across major ecological types provides basic information on stand dynamics, responses to different harvesting regimes and site preparation, and effects on a variety of forest values. Data from these installations help calibrate growth and yield estimates with silvicultural practices.

The ecology activity includes the Biogeoclimatic Ecosystem Classification system, probably one of the best-known provin- cial research success stories. Originated by Dr. Vladimir Krajina at the University of British Columbia, the concept now provides the ecological framework that underlies all aspects of today's forest management practices in BC. Ecology research is diverse and currently includes development of management practices to restore fire-origin ecosystems, to enhance botanical forest products and to enable co-existence of harvesting in areas of importance to sensitive wildlife. Work is also continuing on extending practical applications of ecosystem classification, the latest being classification of wetlands.

The earth sciences activity covers water, soils, climate and geomorphology. Research into riparian management, fish habitat, potable water supplies and soil erosion have provided the technical foundation for Coastal and Interior Fish/Forestry guidelines, watershed assessment procedures, slope stability hazard ratings and many other operational applications. Research scientists participate in an international network of soil productivity studies that assess the long-term effects of soil disturbance.

What does the future hold for forest science? We see a continued and even heightened demand for research innovations on which to base forest management policies and practices. An increasingly knowledgeable workforce, the public, and international consumers all want assurances that forests are being cared for in a sound manner, and that solutions for integrating land uses are based on credible scientific knowledge. Changing management practices are creating an urgent demand for knowledge about growth processes in mixed-wood stands, and the silvicultural and ecological implications at the stand level of partial harvesting systems. There is a continuing need for more comprehensive information about how to sustain ecosystems and to manage forests for a variety of resource uses. There is a burgeoning demand for research to support improved forest productivity, to rationalize investments, and to provide a forest stewardship framework for streamlined administrative processes including area-based management and innovative tenures.

Progressing on these fronts requires the collective efforts of the Forest Science Program and many other science providers. Through partnerships with universities, institutes, government agencies, the forest industry and others in both research and extension, the delivery model of forest science in British Columbia is continuing a trend that has served well for over 80 years. Now, however, that need for scientific knowledge is greater than ever. Continued success will require innovative approaches through multi-agency planning and priority-setting processes, to ensure that combined staff and resources are directed in the most efficient and effective manner.

The success of the Forest Science Program to date is a tribute to the succession of many committed researchers and administrators who have focussed their energies on improving forest management in the province. Their legacy of knowledge, publications and long-term data series provides both a scientific foundation and an inspiration for continuing generations of bright, energetic scientifically-trained individuals to find innovative solutions to future forest management issues. More information about the British Columbia Forest Service's Forest Science Program can be found at www.for.gov.bc.ca/forsci 